\title{
Psychosociální aspekty nadváhy a obezity dětí raného a předškolního věku v kontextu vybraných sociodemografických ukazatelů v ČR a v některých dalších zemích
}

\author{
Hana Včelařová, Miroslav Chráska, Jana Martincová, \\ Pavla Andrysová
}

\begin{abstract}
Abstrakt: Autoři přehledové studie seznamují s výsledky výzkumů z oblasti sociální pedagogiky, vztahující se k prevenci dětské nadváhy a obezity a s ní související výchovou ke zdravému životnímu stylu. Psychosociální aspekty nadváhy a obezity dětí raného a předškolního věku jsou sledovány v kontextu vybraných sociodemografických ukazatelů v ČR, ve Velké Británii, v USA, Austrálii, některých evropských zemích, Íránu a v Číně. Účelem takto zaměřených výzkumů je nalézání vhodných preventivních, pedagogických a terapeutických zásahů, které by z hlediska rozvoje dětské nadváhy a obezity přispívaly k eliminaci rizikových faktorů v jednotlivých společnostech.

Ukazuje se, že z hlediska psychosociálních a sociodemografických aspektů nelze nadváhu a obezitu dětí v podmínkách konkrétních zemí vždy jednotně popsat nebo vymezit. Odlišné psychosociální nebo sociodemografické charakteristiky jsou nalézány při srovnávání různých etnik, různých věkových kohort rodičů nebo vývojových období dětí, při srovnávání různě vyspělých společností, nebo dokonce jen při srovnávání různých socioekonomických vrstev téže země. Rovněž se ukazuje, že vztahy, zjištěné $v$ príspěvku uvedenými výzkumy, nepůsobí prímočaře, ale mohou být modifikovány působením dalších proměnných. Společným rysem dětské nadváhy a obezity ve většině zemí se zdá být jejich souvislost s výraznějšími sociálními nerovnostmi uvnitř konkrétní země. Zmírnění nerovností makroekonomické společnosti považují tedy někteří autoři za další možný způsob boje proti nadváze a obezitě.
\end{abstract}

Klíčová slova: děti s nadváhou a obezitou, psychosociální činitelé, předškolní věk, raný věk, sociodemografické ukazatele

\section{1 ÚVOD}

Obezita je multifaktoriálně podmíněná metabolická porucha charakterizovaná zmnožením tělesného tuku. Je důsledkem interakce genetických dispozic s faktory zevního prostředí (Aldhoon Hainerová, 2009, 15).

Vysoký výskyt nadváhy a obezity v populaci je celospolečenský problém, na jehož řešení se dlouhodobě a z různých úhlů pohledu aktivně podílí nejen zdravotníci, psychoterapeuti, fyzioterapeuti, výživoví specialisté, ale i sociální a další pedagogové (Butland et al., 2007; Hainer a kol., 2011; Havlínová a kol., 2006; Owen, 2012, 11; Potměšilová a kol., 2013; Varness et al., 2009). Celosvětově se dokonce hovoří o pandemii, kdy se zdá jasné, že na tuto poruchu již není možné nahlížet jen jako na důsledek individuální nekázně a individuálního životního stylu. Odborníci v naší zemi i vahraničí proto $v$ souvislosti s nadměrnou tělesnou hmotností populace a s náklady, které její léčba vyžaduje, obracejí pozornost $k$ životním podmínkám lidí v technologicky vyspělých a rozvojových společnostech obecně. Výzkumy z většiny zemí rovněž dokazují, že nadváha a obezita dospělé části populace je velmi těsně (a to nejen geneticky) spjata s nadváhou a obezitou jejích dětí: zdravotním stavem a životními 
podmínkami matek v období těhotenství, ale i před ním a po něm, podmínkami a životním stylem rodin a komunit, $v$ nichž tyto děti vyrůstají aj. Většina psychických nebo fyzických nápadností (např. extrémní štíhlost, exotický vzhled aj.) jsou provázeny psychosociálními okolnostmi, které mohou znesnadňovat vybočení z určitých stereotypů, a tím do určité míry ovlivňovat osud svých nositelů. I nadváha a obezita jsou spojovány s komplikacemi psychosociálního charakteru: onemocnění je mj. specifické tím, že jedním z jeho „spouštěčü může být právě chronický stres, který aktivizuje zatím dřímající dědičné dispozice a spolu s dalšími vlivy vnějšího prostředí pomáhá rozvíjet způsoby chování, které nakonec vedou $\mathrm{k}$ jeho vzniku. $Z$ hlediska psychologie a psychosomatiky Ize tento moment považovat za počátek bludného kruhu, protože již vzniklá obezita poznamenává oblasti sociálního života svých nositelů dalšími stresovými situacemi. V odborné literatuře je uváděno, že právě chronicky přetrvávající a neřešený stres, at již u lidí s obezitou, nebo u lidí s jinými a na podobných principech založenými obtížemi, může vést $\mathrm{k}$ potlačení imunitního systému a $\mathrm{k}$ výrazným změnám $\mathrm{v}$ činnosti hypotalamu (Asbjørn et al., 2010), které přispívají ke snazšímu rozvoji psychosomatických, zdravotních obtíží ( $v$ závislosti na typu konstituce, na genetických dispozicích, tj. také vlivem působení rodiny v raném věku dítěte aj.).

V naší i v zahraniční odborné literatuře se vedou diskuze o tom, zda lidé s nadváhou a obezitou reagují při střetu s různými výzvami osudu netypicky, a pokud ano, tak jaké zdravotní, psychosociální, ekonomické a jiné životní okolnosti je $k$ tomu vedou nebo jim brání ve změně (např. Burkert et al., 2013; Maio et al., 2007). Většina teorií též potvrzuje, že se přitom nedá prokázat typická osobnostní struktura lidí s obezitou a že tito lidé netvoří osobnostně homogenní skupinu (Hainer, 2009, s. 261).

Psychosociální aspekty nadváhy a obezity jsou odborníky většinou zkoumány ze dvou hlavních perspektiv: z perspektivy těch sociodemografických charakteristik obyvatelstva (etnických skupin, komunit, rodin), o nichž se předpokládá, že se podílely na změnách životního stylu, a tím i na rozvoji nadváhy a obezity u značné části populace, a z perspektivy důsledků této poruchy pro sociální postavení, pro profesionální a osobní život lidí s nadváhou a obezitou.

$\checkmark$ př́spěvku se budeme věnovat psychosociálním aspektům nadváhy a obezity z hlediska obou výše uvedených perspektiv, a to $v$ návaznosti na prevalenci této poruchy u dětí raného a předškolního věku v naší i v některých dalších zemích. Výsledky takto zaměřených výzkumů přinášejí cenná zjištění právě pro účely preventivních, pedagogických a terapeutických intervencí. Ty jsou v prípadě dětí raného věku organizovány $v$ rámci práce $s$ celými rodinami nebo $s$ některými rodinnými členy. Tentýž přístup je možné uplatnit také u dětí předškolního věku, zde však již lze možnosti prevence a intervence rozšírit o programy přímo působící v mateřských školách.

\section{DĚDIČNÁ PODMÍNĚNOST A DALŠí RIZIKOVÉ FAKTORY ROZVOJE NAD- VÁHY A OBEZITY V RANÉM A V PŘEDŠKOLNÍM VĚKU}

Více odborných zdrojů se shoduje na tom, že z mnoha faktorů, které se na rozvoji nadměrné tělesné hmotnosti podílejí, se většina prípadů dětských pacientů s nadváhou a obezitou ještě nedá vysvětlit pouze genetickými vlivy či hormonálními poruchami (Müllerová, 2011; Aldhoon Hainerová, 2009). Rodiče těchto dětí trpí často nadváhou a obezitou také, takže zde společně pưsobí genetické i environmentální vlivy.

V odborné literatuře bývá uváděno větší množství mezinárodně uznávaných, rizikových faktorů vzniku nadváhy a obezity (Butland et al. 2007, Gudersen et al., 2007, Howel et al., 2013, Aldhoon Hainerová, 2009, 31; Hainer, 2011, 78); zde uvádíme především ty, jejichž platnost byla ověřena i ve vztahu $k$ populaci českých dětí a $k$ době prenatálního, raného a předškolního věku.

Ve vztahu k rozvoji nadváhy a obezity v dětství byl prokázán vliv celkového zdravotního stavu a výživy matek v období těhotenství a nedlouho před ním (Kunešová, Tláskal, 2013). Mezi rizikové faktory dále patří vysoká i nízká porodní hmotnost dětí. Kouření matek vede k nižší porodní hmotnosti dětí 
a v pozdějším věku je spojováno s častějším rozvojem obezity (Kunešová, Tláskal, 2013). Se sníženým rizikem vzniku nadváhy u českých dětí souvisí dle výzkumů také prodloužené kojení; kojení kratší než tři měsíce tento ochranný vliv na vznik nadváhy v dětském věku nemá. Inverzní vztah mezi prodlouženým kojením a rozvojem nadváhy nebyl prokázán u dětí všech etnických skupin (Jančíková, 2004).

Skladba lidského těla prochází změnami, které souvisejí s růstem. Některé zdroje popisují kolísání množství tukové tkáně, jiné zdroje hovoří o postupném nárůstu body mass indexu (dále jen $\mathrm{BMI}$, nebo také BMI percentilové hodnoty, které se u dětí používají častěji) až do 10. měsíce věku z důvodu růstu dítěte do délky a souběžného zmnožení tukové tkáně (Mrosková et al., 2012). Následně hodnota BMI klesá až do doby, kdy dosahuje v období mezi 4. -6. rokem fyziologicky nejnižší úroveň. Poté dochází opět k vzestupu BMI, a to až do ukončení růstu dítěte. Okamžik odrazu BMI se nazývá adiposity rebound (AR). Ve vztahu $k$ nadměrné tělesné hmotnosti je AR důležitý z toho důvodu, že jeho časný nástup zvyšuje pravděpodobnost rozvoje dětské obezity. Jedna z hypotéz, vysvětlujících př́íčinu časného nástupu AR u některých dětí, tvrdí, že je to dáno energetickým deficitem v raném období, který mohla vyvolat právě umělá výživa dítěte (Aldhoon Hainerová, 2009). Z hlediska pravděpodobnosti vzniku dětské nadváhy a obezity byl dále nalezen vztah mezi BMI rodičů, vzděláním rodičů (zejména matek), existencí sourozenců a velikostí obce, v níž rodina žije.

\section{NADVÁHA A OBEZITA U DĚTí RANÉHO A PŘEDŠKOLNÍHO VĚKU V KONTEXTU NĚKTERÝCH SOCIODEMOGRAFICKÝCH ČINITELŮ V ČR}

Studie o tom, v jakém věku dětí se nadměrná tělesná hmotnost poprvé objevuje, bývají ve všech zemích poměrně vzácné. $V$ následující tabulce využíváme výsledků výzkumu v naší zemi z roku 1999 (Vignerová, Bláha, 2001).

Tabulka 1

Životní obdobi, kdy se ve zdravotní dokumentaci chlapců s obezitou staršich 10 let $(N=2152)$ a dívek sobezitou starších 10 let $(N=3565)$ poprvé objevil údaj o nadměrné tělesné hmotnosti (Vignerová, Bláha, 2001)

\begin{tabular}{lllll}
\hline & Do 1. roku & Mezi 2.-6. rokem & Do 10 let & Do 10 let celkem \\
\hline Chlapci & $35,5 \%$ & dalších 45,5\% & dalších 15,6\% & $96,5 \%$ \\
Dívky & $37,1 \%$ & dalších 43,1 \% & dalších 17,0 \% & $97,2 \%$ \\
\hline
\end{tabular}

Tabulka 2

Stav nadváhy a obezity u dětí předškolního věku v ČR v roce 2001

\begin{tabular}{lllll}
\hline Věk & Nadváha & & Obezita & \\
\hline & Dívky & Chlapci & Dívky & Chlapci \\
$3-5,99$ & $6,6 \%$ & $4,6 \%$ & $5,0 \%$ & $4,6 \%$ \\
\hline
\end{tabular}

$Z$ hlediska prevalence nadváhy a obezity u českých dětí předškolního věku lze konstatovat, že hodnoty body mass indexu se u této skupiny dětí za posledních padesát let spíše snižily. $Z$ hlediska fenoménu adiposity rebound (Kunešová, Tláskal, 2013, Mrosková et al., 2012) však došlo ve srovnání se situací v ČR před 50 lety $k$ nepríznivému posunu nástupu o více než o rok směrem $k$ mladšímu věku (Vignerová a kol., 2007). Již jsme zmiňovali, že časnější nástup odrazu AR bývá spojován s rozvojem nadváhy a obezity v pozdějším věku dětí.

Opačný trend, tj. zvyšování tělesné hmotnosti, Ize u našich dětí pozorovat od 6 let výše a ve srovnání s výsledky z roku 1991 se nárůst v této věkové skupině projevil nejvýrazněji [Vyhledáno 3. 8. 2014 na 
http://www.szu.cz/data/rustove-grafy]. Zpomalení až zastavení trendu zvyšování průměrné tělesné hmotnosti bylo patrné u dospívající populace.

Podobně jako v některých zahraničních výzkumech i v podmínkách naší země se prokázalo sepětí dětské nadváhy a obezity s následujícími skutečnostmi: děti s nadváhou nebo obezitou údajně častěji vyrůstají bez sourozenců, existuje přímá souvislost mezi tělesnou hmotností dětí a BMI jejich rodičů (zejména matek), existuje inverzní vztah mezi tělesnou hmotností dětí a úrovní vzdělání jejich rodičů (zejména matek). Ve srovnání s minulostí se méně výrazně potvrdil vztah mezi tělesnou hmotností dítěte a velikostí obce, v níž dítě žije (Kobzová a kol., 2003). Skutečnost, že pražské děti patřily ve výzkumech vždy mezi nejštíhlejší, byla spojována s nejvyšším podílem středoškolsky a vysokoškolsky vzdělaných rodičů. $V$ roce 2001 však patřily na druhé místo, a to po městech, které měly nad 100000 obyvatel. Autoři výzkumu se domnívají, že tato změna by mohla souviset se společenskými změnami, k nimž u nás po roce 1989 došlo (větší tlak na zaměstnanost matek, nástup zahraničních firem s rychlým občerstvením v našich městech, všudypř́itomné reklamy propagující životní styl, který není přiliš slučitelný s víkendy v domácím prostředí a s přípravou domácí stravy aj.).

Ve srovnání s minulostí se život většiny dětí předškolního věku již neodehrává při společných hrách na ulicích. Čas těchto dětí začíná být více organizovaný a MŠ přestávají být jedinou alternativou dopoledního pobytu dětí. Mění se složení společnosti a vztahy mezi jednotlivými vrstvami, což se u dětí předškolního věku zatím nejvíce odráží v odlišných skladbách jejich aktivit, rozvíjených sportovních činnostech aj. Je zřejmé, že ve své podstatě jde o jeden z důsledků celospolečenských změn, jaké reflektuje právě sociální pedagogika, $\mathrm{k}$ jejímž cílům, mimo jiné, patří i nalézání východisek, které za daných společenských podmínek pomáhají rozvíjet osobnost každého člověka (Procházka, 2012).

U českých otců ve srovnání s předešlými lety narůstají hodnoty BMI, což může svědčit jak o nárůstu nadváhy a obezity, nebo ( $v$ některých případech) o nárůstu svalové hmoty otců v důsledku moderních aktivit v posilovnách. U některých kohort českých matek je opačný trend - přibývá matek s nižší tělesnou hmotností, jejichž BMI směřuje pod hranici normy.

$\checkmark$ roce 2008 došlo ve srovnání s rokem 2001 poprvé ke zvýšení prevalence obezity pouze u sedmiletých chlapců, zatímco prevalence obezity u dívek a prevalence nadváhy u obou pohlaví mladšího školního věku se v ČR snižila (Hainer, 2011, 19). To se zdá být vzhledem k výše uvedeným zjištěním o nejvyšším nárůstu nadváhy a obezity dětí právě tohoto věku pozitivním zvratem. Aktuálnější a celoplošněji zaměřené informace o stavu dětské nadváhy a obezity v naší zemi bohužel zatím nemáme.

\subsection{Velká Británie}

Dle britské The National Child Measurement Programme for England (dále jen NCMP), která ročně vyhodnocuje výšku a váhu dětí v tzv. Reception class (věk 4-5 let) a žáků 6. tříd základních škol (věk 10-11 let), byl na hranici let 2010/11 ve Velké Británii konstatován tento stav: u 4-5letých dětí byla zjištěna nadváha nebo obezita u $22,6 \%$. Procento dětí s obezitou ve věku $4-5$ let $(9,4 \%)$ bylo téměř dvakrát nižší než procento dětí s obezitou ve věku 10-11 let (19,0 \%). Ve srovnání s britskými kritérii pro nadváhu a obezitu jsou česká kritéria mírnější (Aldhoon Hainerová, 2009, 15): znamená to, že za užití britských kritérii by počet českých dětí, které by byly hodnoceny jako trpící nadváhou nebo obezitou, stoupl. Prevalence dětské obezity je v konkrétních oblastech Anglie odlišná a liší se také při srovnání městských a venkovských oblastí (s vyšší prevalencí ve městech). K regionálním rozdílům dále přispívají rozdíly dle věku, socioekonomického statusu, etnicity aj. Výskyt nadváhy a obezity ve sledovaných věkových skupinách zřejmě přímo souvisí s hodnotami BMI obou rodičů. Dle výše uvedeného zdroje se zdá, že výskyt obezity ve Velké Británii naznačuje přechod ve vztahu k sociální tř́dě: děti z rodin s nejvyššími př́ijmy jsou méně často a méně obézní než děti z rodin s nejnižšími příjmy.

Jak však naznačují výsledky dalšího podobně zaměřeného výzkumu v této zemi (Hawkins et al., 2008), tak vztah mezi výší př́ijmu rodin a rozvojem dětské obezity se vždy neprojevuje takto prrímočaře. U kohorty 13113 dětí-jedináčků, narozených mezi lety 2000-2002, autoři výzkumu zjištovali jejich 
porodní hmotnost, délku, údaje o BMI rodičů a některé další údaje osobní a pracovní anamnézy rodičů. Rodiče byli kontaktováni ve věku 9 měsíců a tří let dětí. Ve třech letech byla zjištěna nadváha u 23 \% (tj. 3085) ze všech dětí. Na základě statistické analýzy všech údajů bylo zjištěno, že pravděpodobnost nadváhy stoupala s každými 10 hodinami zaměstnání matky za týden, což však platilo jen u rodin s určitou výší ročního př́ijmu a neplatilo to pro rodiny nižších příjmových skupin. Nebyl nalezen vztah mezi zaměstnaností matčina partnera a dětskou obezitou. Autoři výzkumu uzavírají, že ve Velké Británii se dlouhé hodiny matčina zaměstnání (spiše než nedostatek peněz) zdají být hlavní překážkou v přístupu dětí ke zdravé výživě a $\mathrm{k}$ fyzické aktivitě. Pravděpodobnost nadváhy byla vyšší u dětí, jejichž matky referovaly o tom, že kvůli práci nemají čas na své děti, a u dětí, které byly hlídány dalšími členy rodiny (strýčky, partnery aj., tj. neformální péčí) než zaměstnankyněmi různých agentur (tj. formální péčí). Výsledky výzkumu autoři dále ještě specifikují z hlediska etnických odlišností (vyšší podíl nadváhy u dětí etnických menšin nebo u dětí smíšených etnik), druhu zaměstnání (v neprospěch stereotypních, manuálních zaměstnání), kouření matek atd.

Výsledky dalšího britského výzkumu (Howel et al., 2013) se sice nevztahují k nadváze a obezitě dětí předškolního věku, ale vzhledem $k$ prokázané těsnosti propojení mezi obezitou rodičů a jejich dětí, je zde uvádíme. Vědci se na vzorku složeném z více kohort dospělých věkových skupin (celkem 155661 lidí v letech 1993-2008) snažili ověřit, zda se dříve zjištěné sociálně-ekonomické vzory, typické pro respondenty $s$ nadváhou a obezitou, $v$ průběhu času mění. Výsledky ukázaly, že $z$ hlediska demografických faktorů, které byly sledovány již dříve, se přes určité drobné posuny podstatné podíly respondentů s manuálním nebo s nemanuálním povoláním, s vyšším nebo s nižším vzděláním, s celým nebo $s$ částečným úvazkem a s dalšími charakteristikami ve srovnání s předchozími výzkumy zatím podstatně nezměnily. Jak autoři upozorňují, síla vztahů mezi sociálně-ekonomickým statusem (dále jen SES) a prevalencí nadváhy a obezity je ovlivňována způsobem nastavení konkrétních kritérií SES.

Ve Velké Británii se klade v boji proti dětské nadváze a obezitě velký důraz na prevenci, což platí hlavně pro práci v rámci rodin a různých komunit. Se vzrůstajícím ekonomickým napětím a s tím současně se oslabujícími možnostmi poskytování celoplošné péče, je zdůrazňován význam individuální odpovědnosti jedinců a vzájemné podpory rodinných členů. Mnoho britských studií se s důrazem na konkrétní praktická opatření ze strany např. sociálních pedagogů, pracovníků sociální práce a jiných profesí zabývá podmínkami rodin a komunit v tzv. „obesogenic“ prostředích (Edwards et al., 2010), která jsou zpravidla velmi chudá, nezř́íka i etnicky odlišná a jejichž životní styl je z více prríčin jen obtižně tvarovatelný.

\subsection{Situace v USA}

Dle některých současných zdrojů (World Health Organization (WHO), 2012, Hainer, 2011,19) patří dětská populace $v$ USA $k$ těm $s$ nejvyšší prevalencí nadváhy a obezity. To bohužel platí i pro prípady extrémní obezity dětí, která může vyústit až v ohrožení života (Varness et al., 2009). Původní odhad WHO, že v roce 2010 bude činit podíl amerických dětí s nadváhou a obezitou $40 \%$, se vzhledem ke všem zaváděným opatřením snad nenaplnil (Hainer, 2011, 19). Ze značného množství výzkumů, které se $v$ souvislosti s monitorováním efektu různých zaváděných opatření realizovaly, vybíráme několik niže uvedených, které se ve shodě se zaměřením našeho příspěvku věnovaly sociodemografickým a psychosociálním aspektům nadváhy a obezity amerických dětí raného a předškolního věku.

V rámci studie „Fragile Families and Child Wellbeing study“ proběhl výzkum (Whitaker et al., 2007) zjištúující, zda je obezita spojena se špatným zacházením/týráním dětí předškolního věku. Bylo zde sledováno 2412 dětí narozených v letech 1998-2000 ve 20 velkých městech 15 států USA. Ve věku tř́ let každého dítěte byla změřena výška a váha dětí. Matky dětí odpovídaly na položky dotazníku Parent Child Conflict Tactics Scales o různých typech nedostatečné péče nebo špatného zacházení s dětmi z jejich strany. Za účelem zmírnění psychických zábran při přiznávání prohřešků ze strany matek byly dotazy směřovány na výskyt takového jednání $v$ uplynulém roce $s$ verzemi občas/jednou/nikdy. 
Ve věku tři let byla z celkového počtu dětí zjištěna obezita u $18 \%$, epizody nedostatečné péče přiznávaly matky v $11 \%$, tělesné tresty v 84 \% (zpravidla ve formě bití dítěte po zadku kovovou tyčí, plácáním dítěte přes ruce a nohy, štípáním) a psychické trápení/týrání dětí v 93 \% (zpravidla ve formě hrozby odeslání do ústavní péče, označování dítěte jako hloupého nebo vyhrožování tělesným trestem, který se neuskutečnil). Na základě statistické analýzy všech údajů byl zjištěn prímý vztah mezi vznikem obezity dítěte a nedostatečnou péčí o ně, mezi obezitou a počtem dětí v domácnosti, mezi obezitou a př́slušníky některých etnických skupin, mezi obezitou dítěte a rodinným stavem matky (vyšší pravděpodobnost u svobodných matek), prímý vztah mezi obezitou dítěte a BMI rodičů, prímý vztah mezi obezitou dítěte a kouřením matky během gravidity, prímý vztah mezi obezitou dítěte a věkem matky, mezi obezitou dítěte a jeho pohlavím, prímý vztah mezi obezitou dítěte a jeho porodní hmotností. Frekvence fyzických trestů a psychického trápení nebyly spojeny se zvýšeným rozvojem obezity. Téměř polovina všech dětí pocházela z rodin, které byly pod federálně vymezenou hranicí chudoby. Tyto americké rodiny často žijí v přívěsech aut a cestují za pracovními príležitostmi. Výzkumu se účastnily matky různých etnických skupin, jejichž poměr nebyl vyrovnaný. 29,6 \% matek neukončilo střední školu, 68,8 \% matek nebylo vdaných, 18,8 \% matek rodilo ve věku pod 20 let a 41,3\% těchto žen trpělo obezitou. Epizodu nedostatečné péče přiznávaly častěji ženy svobodné, méně vzdělané, s nižším príijmem domácnosti a s různou etnickou příslušností. Výskyt obezity byl významně vyšší u dětí, jejichž matky přiznávaly v minulém roce epizodu nedostatečné péče, než u dětí, jejichž matky tuto epizodu neohlašovaly nikdy.

Autoři vysvětlují zjištěné skutečnosti takto: v raném dětství zprostředkují hlavní vlivy prostředí rodiče. Podílí-li se charakter interakcí mezi dětmi a jejich rodiči na utváření neurobehaviorálních a neuroendokrinních reakcí dětí na stres, potom sociální a emocionální aspekty těchto interakcí mohou ovlivnit riziko vzniku obezity i v prípadech, kdy se tyto interakce netýkají výživy. Stres ovlivňuje př́ijem jídla, ovlivňuje aktivitu a spontaneitu dítěte. Nedostatečná péče působí ve srovnání s fyzickými tresty nebo s psychickým týráním méně drasticky, může se však projevovat naprosto nečekaně a stejně jako fyzické tresty si ji dítě může vykládat jako odplatu za svá domnělá provinění.

V mnoha studiích byl prokázán vztah mezi sexuálním zneužíváním dívek a obezitou $v$ dospělosti (Whitaker et al., 2007), v tomto výzkumu však nebylo zkoumáno ani těžké fyzické týrání, ani sexuální zneužívání. Častou frekvenci tělesných trestů a psychické agrese vůči sledovaným dětem autoři dávají do souvislosti s obdobím zvýšené motorické aktivity dětí raného věku, kdy děti projevují vývojově přirozený sklon zkoumat své okolí a prosazují svou autonomii.

Autoři upozorňují, že nejsou schopni dělat závěry o příčinných souvislostech: teoreticky zde může působit více proměnných (např. složení stravy, míra fyzické aktivity aj.), i když předchozí studie dětí raného věku konzistentní vztahy mezi takovými proměnnými a obezitou neprokázaly (Reilly et al., 2005). Doporučují zaměření dalších výzkumů na vztahy mezi stresem u dětí raného věku a mechanizmy mozku, které regulují chut' k jídlu a pohybovou aktivitu dětí. Je-li nedostatečná péče o děti důsledkem chronicky nepríznivých životních podmínek dospělých, potom bude vhodné rozšírit strategie prevence o prvky, které by těmto situacím pomáhaly čelit.

Studie, mapující vztah mezi prevalencí obezity u dětí raného věku v Oklahomě, kde žijí etnicky různorodé rodiny s nižšími přijmy, upozorňuje na význam přesnosti těchto údajů pro poskytování oficiálně organizované podpory rodinám s nízkým SES (Weedn et al., 2012).

Přínosná je rovněž studie, která nachází vztahy mezi výskytem nadváhy a obezity amerických dětí předškolního věku a každodenním rutinním chováním $v$ těchto rodinách (Blake et al., 2014). Rutinním chováním se míní zvyklosti, které souvisejí s rytmy pracovních i víkendových dní, s dobou spánku, se společně podávanými jídly aj.

Většina podobně zaměřených amerických výzkumů vychází z údajů rodin s nižšími př́ijmy. Je to tím, že rodiny s nižšími př́ijmy jsou více v kontaktu s podpůrnými institucemi, jejichž činnost se odvíjí i od evidence prípadů vyžadujících pomoc. Dalším možným důvodem je, že rodiny s nižším SES jsou ve 
srovnání s rodinami s vyšším SES více otevřené komunikaci o problémech svých dětí s nadváhou a obezitou.

Výsledky 11 amerických výzkumů, s odlišnými velikostmi vzorků a různými věkovými skupinami dětí, srovnávají autoři dalšího př́spěvku (Gudersen et al., 2011). Z hlediska existujících vztahů mezi obezitou dětí předškolního věku a různými sociodemografickými proměnnými bylo věnováno hodně pozornosti informacím o zdravé výživě, ale také o rozvíjení schopností dětí vypořádávat se se stresem a adaptivně zvládat různé druhy psychické zátěže. Tělesný pohyb není v těchto výzkumech chápán jako samoúčelná aktivita, ale jako jeden ze způsobů udržujících duševní pohodu a pomáhajících snižovat zátěž.

Autoři studie uvádějí, že v USA během několika posledních desetiletí narůstaly ekonomické nerovnosti. Situace je spojována s důsledky ropné krize, o níž se hovoří od 70 . let minulého století. Jedním z průvodních jevů této zvyšující se zátěže na rodiny může být zvýšená prevalence dětské nadváhy a obezity. Autoři vyslovují přesvědčení, že kromě pokračujících preventivních, pedagogických a terapeutických opatření $v$ rámci boje proti nadváze a obezitě by bylo vhodné usilovat o snižení nerovností makroekonomické společnosti.

\subsection{Situace v Austrálii}

Zdá se, že o něco příznivější výsledky přinášejí podobně zaměřené výzkumy v Austrálii. V australském státě Victoria byl proveden výzkum na základě záznamů ve zdravotní evidenci 129266 matek dětí raného a předškolního věku (Nichols et al., 2011). Zjistilo se, že kombinovaná prevalence nadváhy a obezity mezi lety 1999 až 2007 se u 3,5letých dětí snízila o 3,1 \% (z 18,5 \% na 15,4 \%) a u 2letých dětí o $1,1 \%$ (z $13,5 \%$ na $12,4 \%$ ). Zvláště uspokojivé na zjištěných výsledcích je, že se současným poklesem dětské nadváhy a obezity nedošlo $v$ uvedeném období ke zvýšení četnosti dětské podváhy. Výskyt nadváhy a obezity dvouletých dětí v oblasti s nejvyšším SES znevýhodněním přesto zůstává o 2,3 \% vyšší než v oblasti s nejmenším SES znevýhodněním. Vliv sociálního gradientu na prevalenci dětské nadváhy a obezity zůstává tedy patrný i při zúžení socioekonomických rozdílů, knimž v posledních letech v Austrálii došlo.

Ve Victorii byla v posledním desetiletí realizována řada iniciativ (např. de Silva-Sanigorski et al., 2010) zaměřených na podporu správné výživy, tělesné aktivity a zdravé hmotnosti v raném dětství, a to $s$ důrazem na populaci v socioekonomicky znevýhodněných oblastech. Tyto iniciativy byly realizovány $v$ mnoha různých institucích, např. také v mateřských školách, a je tedy samozřejmé, že se na jejich provedení podíleli i pedagogičtí pracovníci. Je také možné, že nepříznivý trend výskytu nadváhy a obezity se začíná obracet u malých dětí, které se jako první vymaňují z epidemie. Naopak se zdá nepravděpodobné, že by zvrácený trend $v$ prevalenci dětské nadváhy a obezity způsobily změny oblastí z hlediska převažujícího typu SES znevýhodnění, protože $k$ tak výrazným posunům $v$ posledních devíti letech údajně nedošlo.

Ve výzkumu v Novém Jižním Walesu bylo sledováno 764 dětí ve věku 2-5 let, které pravidelně docházely do center dětské péče. $11 \%$ z těchto dětí bylo potomky domorodých obyvatel Aus-trálie (Wolfenden et al., 2011). Ukázalo se, že po zohlednění věku dítěte a počtu hodin péče o děti v těchto centrech za týden, zůstalo významným prediktorem tělesné hmotnosti dětí jen vzdělání matky. Nebyly zjištěny významné rozdíly mezi službami center, počty dětských respondentů nebo dobou provozu center. Vysoká prevalence nadváhy a obezity domorodých dětí ve srovnání s dětmi ostatních etnik vyvolává otázku, zda tomu tak v populaci domorodých dětí bylo vždy. Autoři výzkumu nabízejí k úvaze myšlenku, že chtějí-li v podmínkách své země snižit riziko nadváhy a obezity u dětí předškolního věku, potom je nezbytné se zaměřit na zdravou výživu a fyzické aktivity těchto dětí v jiných prostředích než jen v domácích.

Z hlediska našeho sociokulturního cítění nám zřejmě budou bližší výsledky australského výzkumu o vztahu mezi dětskou obezitou a výchovnými styly v rodinách 4983 dětí ve věku 4-5 let. Autoři zde mj. dospívají k závěru, že z hlediska takto zvažovaných vztahů se pro zdravou tělesnou hmotnost dětí 
Včelařová, Chráska, Martincová \& Andrysová / Psychosociální aspekty nadváhy a obezity ...

jeví jako nejvýznamnější emočně vřelá a současně pevná, autoritativní výchova otců (Wake et al., 2007).

\subsection{Situace v prevalenci nadváhy a obezity dětí předškolního věku v Evropě; prevalence nadváhy a obezity u dětí evropských migrantů}

Stralen et. al. (2012) referují o prevalenci nadváhy a obezity u evropských předškoláků ve věku 4-7 let. Byly provedeny analýzy šesti evropských datových sad (Belgie, Bulharsko, Německo, Španělsko, Řecko, Portugalsko). Výskyt nadváhy a obezity v jednotlivých zemích kolísal v př́padě nadváhy od $8 \%$ až ke $30 \%$ a v prípadě obezity od $1 \%$ až ke $13 \%$, s nejvyšší prevalencí v jihoevropských zemích (Španělsko a Řecko). I v případech těchto zemí byla vyšší pravděpodobnost nadváhy nebo obezity shledána u dětí rodičů s vysokým BMI nebo s nízkým SES. Kritéria nadváhy a obezity dle WHO prokázala hodnoty od 0,6 \% (chlapci v Belgii) až po 12 \% (dívky v Řecku). Z hlediska výskytu obezity bylo u obou pohlaví nejvíce obézních v Řecku, následovalo Španělsko, Bulharsko, Polsko, Německo a Belgie. $\checkmark$ České republice činí dle kritérií WHO prevalence obezity 3-5letých dětí asi $3 \%$, umístili bychom se tedy asi za Polskem a před Německem. Znamená to, že za užití kritérií WHO se u polských 3-5letých dětí vyskytuje obezita častěji než u našich dětí stejného věku.

Ve výzkumné studii u dánských 3-5letých dětí výsledky ukázaly, že v této věkové skupině zůstává výskyt nadváhy a obezity na $10 \%$ a za deset let se $v$ této populaci z uvedeného hlediska neprojevily žádné výrazné změny (Larsen et al., 2011). Nadváha a obezita dětí v pěti letech věku byla silně spojena s nadváhou a obezitou dětí ve třech letech, dále potom s jejich porodní hmotností a s pohlavím.

V dalším zdroji (Labree et al., 2011) jsou popisovány výsledky studie vycházející z několika renomovaných databází za účelem posouzení stavu nadváhy a obezity mezi dětmi a adolescenty migrantů ve srovnání s pưvodními obyvateli konkrétních evropských zemí.

$\checkmark$ posledních 50 letech se mnoho evropských zemí změnilo na přistěhovalecké společnosti. Docházelo k tomu jak v důsledku získávání nezávislosti bývalých kolonií, tak i většími pracovními a vzdělávacími př́ležitostmi v evropských zemích, potřebou levných pracovních sil, a to vše $v$ časté kombinaci s politickými důvody v rodných zemích migrantů. Proběhlo několik takových „toků“ migrantů směrem do Evropy, a mnohé evropské země tak zaznamenaly velké změny ve složení obyvatelstva. Mnoho migrantů zaujalo z hlediska SES v nových zemích znevýhodněné pozice, což poznamenalo zdravotní stav této části populace. Předpokládá se, že $v$ důsledku změn v životním stylu nacházíme $u$ jednotlivých skupin migrantů zvýšené množství určitých chorob, a to včetně vyššího rizika nadváhy a obezity. Migranti údajně inklinují k sedavému způsobu života, k opouštění svých původních návyků i tradičních jídel a přijímají západní styl stravování. Kromě toho migranti pocházející z nejméně rozvinutých zemí si do nových zemí přinášejí předsudky v podobě preference větší velikosti těla (ta je $v$ jejich původních zemích považována za projev zdraví a bohatství). Většina studií však např. nesrovnává sociokulturní charakteristiky etnicky odlišných skupin migrantů, přestože ovlivňují jejich umístění na pozicích SES v nových zemích. Málo se rovněž sleduje vztah mezi prevalencí nadváhy a obezity a délkou migrace. Ne vždy je přesně zachycena etnická rozmanitost migrantů a je také známo, že každá země prijímá migranty jinak.

Dle kritérií WHO se pohybuje výskyt nadváhy u dětí evropských migrantů od 8,9 \% k 37,5 \%, ve srovnání s rozmezím od 8,8 \% k 27,3 \% dětí původních obyvatel evropských zemí. Výskyt obezity u dětí evropských migrantů se pohybuje od 1,2 \% k 15,4 \%, ve srovnání s rozmezím od 0,6 \% k 11,6 \% dětí původních obyvatel evropských zemí.

\section{5 Írán}

Ve studii íránských autorů (Hajian-Tilaki, Heidari, 2013) bylo za účelem zjištění prevalence nadváhy a obezity relevantním způsobem vyšetřeno 760 předškolních dětí ve věku 2-5 let. Nadváha a obezita dětí byla posuzována na základě tabulek růstu dětí (CDC, 2000). 
Výskyt nadváhy činil bez ohledu na rozdíly mezi pohlavími $11,8 \%$, výskyt obezity $15 \%$. Pravděpodobnost nadváhy/obezity u 4-5letých dětí byla ve srovnání s 2-3letými dětmi téměř dvojnásobná. $Z$ počtu 760 dětských účastníků 375, tj. 49,3\%, byli chlapci a 385, tj. 50,7 \%, byly dívky. Nejvíce dětských účastníků, tj. 67,3\%, se narodilo jako první a pouze 3,3 \% dětských účastníků se ve svých rodinách narodilo jako 3. a další. Z hlediska povolání bylo 59,1 \% matek ženami v domácnosti, $30 \%$ otců bylo podnikateli, $18,7 \%$ otců bylo úředníky, 10,7 \% otců bylo inženýry/lékaři, 5 \% otců pracovalo jako učitelé aj.

Výsledky studie potvrzují vysokou prevalenci obezity a nadváhy u predškolních dětí v této zemi. $Z$ velkého počtu srovnávaných demografických činitelů se jako nejvýznamnější ukázaly vztahy mezi dětskou obezitou a věkem dětí a vztahy mezi dětskou obezitou a obezitou rodičů. Vysoká prevalence dětské nadváhy a obezity se $v$ této zemi vyskytuje souběžně s vysokou prevalencí subnormní tělesné hmotnosti dětí: z hlediska potenciálních zdravotních komplikací to představuje dvojí ohrožení obyvatel rozvojových zemí.

\section{6 Čína}

Vzhledem k nedostatku výzkumů, zaměřených na psychosociální nebo sociodemografické aspekty nadváhy a obezity čínských dětí předškolního věku, uvádíme výzkum čínských autorů, vztahující se k psychosociálním aspektům nadváhy a obezity 130 čínských dětí ve věku 9-14 let (Chen et al., 2014). Děti byly požádány, aby se na základě předkládaných obrázků štíhlých nebo zavalitějších postav vyjádřily $\mathrm{k}$ tomu, zda a do jaké míry by se chtěly stát kamarády dětí $s$ touto postavou. Ukázalo se, že zatímco ženské postavy s nadváhou byly preferovány méně, tak mužské objekty s nadváhou byly preferovány více. Autoři výzkumu konstatují, že stigma typické pro západní kulturu nemusí platit pro kulturu čínskou. Čínská kultura údajně vnímá obezitu jako příjemnou a Číňané zpravidla považují baculaté lidi za žádoucí a atraktivní. Čínští rodiče věří, že obézní děti jsou zdravé a že jejich obezita odráží lásku rodičů k nim.

Autoři výzkumu dodávají, že v Číně jsou dívky ve srovnání s chlapci v mnoha směrech diskriminovány (dívky mají nižší účast na trhu práce, nižší mzdy, často jim chybí základní lidská práva, čínské statistiky udávají vyšší úmrtnost dívek aj.). Je to další důvod, proč může být postoj k obezitě v této zemi z hlediska pohlaví diferenciální. Možná proto vnímají středoškolsky vzdělaní čínští muži čínské ženy s obezitou jako více náchylné $k$ šikanování v zaměstnání, zatímco čínské středoškolsky vzdělané ženy vnímají čínské muže s obezitou jako silné, štastné, s dobrou chutí k jídlu atd. Autoři výzkumu apelují na laskavější jednání vůči ženám ve své zemi a navrhují cíle dalšího, tematicky stejně zaměřeného výzkumu u čínské populace.

\section{ZÁVĚR}

Vysoká prevalence nadváhy a obezity $v$ dětském věku znamená závažný problém. Obezita v dětském věku předurčuje $k$ obezitě $v$ dospělosti, což může znamenat vyšší riziko nemocnosti a předčasné úmrtnosti obyvatelstva vlivem komplikací obezity.

Vznik a rozvoj nadváhy a obezity u dětí raného a předškolního věku jsou spojovány s psychosociálními a sociodemografickými faktory, jejichž význam je odborné veřejnosti dobře známý. Výsledky mnoha tuzemských i zahraničních výzkumů současně potvrzují, že se často jedná o vztahy, které lze měnit nově vstupujícími činiteli nebo posunem nastavení činitelů původních. Tato skutečnost je odborníky pozitivně reflektována právě z hlediska možností „léčby“ celé společnosti, která je dnes již organizována i mezinárodně. Na úrovni jednotlivých států jsou různá praktická opatření v tomto směru zpravidla záležitostí spolupráce více sektorů.

Významné jsou preventivní i různé další pedagogické aktivity, které přispívají k utváření a ovlivňování životního stylu zdravé části dětské populace nebo k identifikaci té její části, která je z hlediska vzniku 
obezity více ohrožena. $V$ těchto oblastech nacházíme tedy i v naší zemi další možnosti uplatnění sociální pedagogiky, která (at' již z hlediska prevence, nebo z hlediska výchovy ke zdravému životnímu stylu) je orientována na pedagogické zásahy přispívající k neutralizaci ohrožujících činitelů v sociálním prostředí (Potměšilová a kol., 2013, 44).

\section{LITERATURA}

Aldhoon Hainerová, I. (2009). Dětská obezita. Praha, Maxdorf.

Asbjørn O. Faleide, Lilleba B., L., Eyolf K., F. (2010). Vliv psychiky na zdraví. Soudobá psychosomatika. Praha, Grada Publishing.

Blake, L., J.,Fiese, H., B., and the Strong Kids Team. (2014). Parent routines, child routines and family demographics associated with obesity in parents and preschool-aged children. Frontiers in psychology, 5, 374. doi: 10.3389/fpsyg.2014.00374

Burkert, N., T., Rásky, E., Großschäft, F., Muckenhuber, J., Freidl, W. (2013). The influence of socioeconomic factors on health parameters in overweight and obese adults. Plos One, 8,6. doi:10.1111/j.1467-789X.2011.00959.x.

Butland, B., Jebb, S., Kopelijan, P., Mc Pherson, K., Sandy T., Mardell, J., and Parry, V. (2007). Foresight. Tackling Obesities: Future Choices - Project Report 2007. Dostupné z: http://www.bis.gov.uk/assets/foresight/docs/obesity/17.pdf

CDC clinical growth charts (2000). Atlanta, Georgia, Centres for disease control and prevention. Dostupné z: www.cdc.gov/growthcharts.

De Silva-Sanigorski, A., Colin B., Kremer, P., Nichols, M., Crellin, M., Smith M., Sharp. S., de Groot, F., Carpenter, L., Boak R., Robertson, N., Swinburn, B., A. (2010). Reducing obesity in early childhood; results from Romp\&Chomp, an Australian community-wide intervention program. American Journal of Clinical Nutrition, 91, 831-840.

Edwards, K., L., Clarke, G., P., Ransley, J., K., and Cade, J. (2010). The neighbourhood matters studying exposures relevant to childhood obesity nad the policy implications in Leeds, Uk. Journal of Epidemiology and Community Health, 64, 3, 194-201. ISSN 0143-005x.

Gudersen, C., Mahatmya, D., Garasky, S., Lohman, B. (2011). Linking psychosocial stressors and childhood obesity. Obesity reviews, 12, e54-e63. doi:10.1111/j.1467-789X.2010.00813.X

Hainer, V. et al. (2009). Základy klinické obezitologie. Praha, Grada.

Hainer, V. et al. (2011). Základy klinické obezitologie. Praha, Grada.

Hajian-Tilaki, K., Heidari, B. (2013). Childhood obesity, overweight, socio-demographic and life style determinants among preschool children in Babol, Northern Iran. Iranian Journal of Public Health, 42, 11, 1283-1291.

Havlínová, M. (ed), Kopřiva, P., Mayer, I., Vildová, Z. a kol. (2006). Program podpory zdraví ve škole; rukovět projektu Zdravá škola. Praha, Portál.

Hawkins, S., S., Cole, T., J., Law, C. (2008). Maternal employment and early childhood overweight: findings from the UK Millenium Cohort Study. Internal Journal of Obesity. 32, 30-38.

Howel, D., Stamp E., Chadwick, J., T., Adamson, A., J., White, M. (2013). Are Social Inequalities widening in generalised and abdominal obesity and overweight among English adults? Plos one, 8,11. doi: 10.1371/Journal.pone. 0079027.

Chen, A., Yin, S., Tang, H., Wang, Z. (2014). An examination of the Mere Proximity Effect of Obesity discrimination in children in Chinese culture. Psychology Research, 4, 4, 265-270, ISSN 21595542. 
Včelařová, Chráska, Martincová \& Andrysová / Psychosociální aspekty nadváhy a obezity ...

Jančíková, B. (2004). Chrání kojení dětí proti nadváze? Neonatologické listy, 10, 1, 35.

Kobzová, J., Vignerová, J., Bláha, P. (2003). Základní tělesné rozměry dětí a mládeže České republiky podle výsledků 6 . Celostátního antropologického výzkumu dětí a mládeže 2001. Česká antropologie, 53, 30-34.

Kunešová, M., Tláskal, P. (2013). Riziková období vzniku a rozvoje obezity u české populace. Sestra, 23, 7-8, 45-47.

Labree, L., J., W., van de Mheen, H., Rutten, F., F., H., Foets, M. (2011). Differences in overweight and obesity among children from migrant and native origin a systematic review of the European literature. Obesity reviews, 12, e535-e547. doi: 10.1111/j.1467-789X.2010.00839.x.

Larsen, M., L., Hertel, N., T., de Pont Christensen, R., Husby, S., Jarban, D., E.(2012). Prevalence of overweight and obesity in Danish preschool children over 10-year period: a study of two birth cohorts in general practice. Acta paediatrica, 101, 201-207. doi:10.1111/j.16512227.2011.02551.x.

Maio, G., R., Haddock, G., G., Jarman, H., L. (2007). Social psychological factors in tackling obesity. Obesity Reviews, 8, 1, 123-125. Doi: 10.1111/j.1467-789X.2007.00330.x.

Mrosková, S., Schlosserová, A., Rel'ovská, M. (2012). Skorá rebound adipozita a její příčiny. Florence, 8, 3, 9-12.

Müllerová, D. (2011). Obezita-prevence a léčba. Praha: Mladá fronta.

National Obesity Observatory. The National Child Measurement Programme for England 2010/11. Dostupné

http://www.noo.org.uk/uploads/doc/vid_13261_NCMP_Changes_IN_CHILDRENS_BMI.pdf.;

nebo $\quad \mathrm{z}$ http://www.ic.nhs.uk/statistics-and-data-collections/health-andlifestyles/obesity/national-child-measurement-programme-england-2010-11-schoolyear.accessed 12.9.2012

Nichols, M., N., de Silva-Sanigorski, Cleary, J.,E., Goldfeld, S., R., Colahan, A., Swinburn, B., A. (2011). Decreasing trends in overweight and obesity among an Australian population of preschool children. International Journal of Obesity, 35, 916-924. doi: 10.1038/ijo.2011.64.

Owen, K. (2012). Moderní terapie obezity. Praha, Maxdorf.

Potměšilová, P., Pospišil, J., Pospiśilová, H., Sobková, P., Hobzová Öbrink, M., Fojtíková Roubalová, M., Straková, V., Najzarová, K. (2013). Sociální pedagogika v teorii a praxi. Olomouc, Univerzita Palackého.

Procházka, M. (2012). Sociální pedagogika. Praha, Grada Publishing.

Reilly, J. J., Armstrong, J., Dorosty, A. R., Emmett, P. M., Ness, A., Rogers, I., Steer, C., \& Sherriff, A. (2005). Early life risk factors for obesity in childhood: Cohort study.British Medical Journal,330, 1357.

van Stralen, M., M., te Velde, S., J., van Nassau F., Brug, J., Grammatikaki, E., Maes, L., de Bourdeaudhuj, I., Verbestel, V., Galcheva, S., lotova, V., Koletzko, B., V., von Kries, R., Bayer, O., Kulaga, Z., Serra-Majern, L., Sánchez-Villegas, A., Ribas-Barba, L., Manios, Y., Chinapaw, M., J., M. (2012). Weight status of European preschool children and associations with family demographics and energy balance-related behaviours: a pooled analysis of six European studies.Obesity reviews, 13, 29-41. doi: 10.1111/j.1467-789x.2011.00959.x.

Tláskal, P. (2006). Obezita dítěte (tuková tkáň, rizikové faktory, prevence). Vox pediatriae, 6, 3, 26-28.

Varness, T., Allen, D., B., Carrel, L., A., Fost, N. (2009). Childhood obesity and medical neglect. Pediatrics 123: 399-406. doi: 10.1542/peds.2008-0712. 
Vignerová, J., Bláha, P. (2001). Sledování růstu českých dětí a dospívajících. Norma, vyhublost, obezita. Státní zdravotní ústav, Praha.

Vignerová, J., Humeníková, L., Brabec, M. et al. (2007). Long-term changes in body weight, BMI and adipozity rebound among children and adolescents in the Czech Republic. Economic and human biology, 5,3, 409-425.

Wake, M., Nicholson, J., M., Hardy, P., Smith, K. (2007). Preschooler Obesity and Parenting Styles of Mothers and Fathers: Australian National Population Study. Pediatrics, 120, 6. doi: 10.1542/peds.2006-3707.

Weedn, E., A., Ang, C., S., Zeman, C., L., Darden, P., M. (2012). Obesity prevalence in low-income preschool children in Oklahoma. Clinical Pediatrics, 51, 10, 917-922. doi: 10. 1177/0009922812441861.

Whitaker, R.,C., Phillips, S., M., Orzol, S., M., Burdette, H., L. (2007). The association between maltreatment and obesity among preschool children. Child Abuse \& Neglect, 31, 1187-1199. doi: 10.1016/j.chiabu.2007.04.008.

Wolfenden, L., Hardy, L., L., Wiggers, J., Milat, J., A., Bell, C., Sutherland, R. (2011). Prevalence and socio-demographic associations of overweight and obesity among children attending child-care services in rural and regional Australiandi, Nutrition§dietetics, 68, 15-20. doi:10.1111/j.17470080.2010.01487.x.

World Health Organization. The WHO Child Growth Standards. Dostupné z http://www.who.int/childgrowth/standards/ends/accessed on 10. 9. 2012

\title{
Autor
}

PhDr. Hana Včelařová, Univerzita Tomáše Bati, Fakulta humanitních studií, Ústav pedagogických věd, Mostní 5392, 76001 Zlín, e-mail: vcelarova@fhs.utb.cz

prof. PhDr. Miroslav Chráska, CSc., Univerzita Tomáše Bati, Fakulta humanitních studií, Ústav pedagogických věd, Mostní 5392, 76001 Zlín, e-mail: chraska@fhs.utb.cz

Mgr. Jana Martincová, Univerzita Tomáše Bati, Fakulta humanitních studií, Ústav pedagogických věd, Mostní 5392, 76001 Zlín, e-mail: martincova@fhs.utb.cz

Mgr. Pavla Andrysová, Ph.D., Univerzita Tomáše Bati, Fakulta humanitních studií, Ústav pedagogických věd, Mostní 5392, 76001 Zlín, e-mail: andrysova@fhs.utb.cz

\section{The psychosocial aspects of overweight and obesity in very young and pre- school children in the context of selected sociodemographic indicators in the Czech Republic and in some others countries}

\begin{abstract}
The authors of this study present the results of surveys in significant areas of social pedagogy relating to both the prevention of overweight and obesity in children, and healthy lifestyle education. The psychosocial aspects of overweight and obesity in early age and preschool children are monitored in the context of selected socio-demographic indicators in the Czech Republic, Great Britain, the USA, Australia, some European countries, Iran and China. The purpose of such oriented studies is to find appropriate preventive, pedagogical or therapeutic interventions that could contribute to the elimination of risk factors in the particular societies.
\end{abstract}


It turns out that the sociodemographic and psychosocial aspects of overweight and obesity in children (in terms of particular countries) cannot be always uniformly described and defined. Numerous psychosocial or sociodemographic characteristics were found when comparing different ethnic groups, the different age cohorts of parents or the different developmental stages of children, when comparing countries with various standards of living, or even just, when comparing different socioeconomic strata within the same country. It also appears that the relationships identified by the below-mentioned researches don't have a straight forward effect, but are also modified by the influence of other variables. A common feature overweight and obesity in children in the majority of countries seems to be associated with significant social inequalities within a specific country. According to some authors, one of the possible ways to fight overweight and obesity in children is to reduce the inequalities of the macroeconomic society

Keywords: Children with overweight and obesity, psychosocial factors, preschool age, early age, socio-demographic indicators 